\title{
New species Tachinid flies (Diptera: Tachinidae) in the Russian fauna
}

\section{Новые виды тахинид (Diptera: Tachinidae) в фауне России}

\author{
A.B. Ruchin ${ }^{1, *}$, T. Zeegers ${ }^{2}$, M.N. Esin ${ }^{1}$ \\ А.Б. Ручин ${ }^{1, *}$, Т. Зигерс ${ }^{2}$, М.Н. Есин ${ }^{1}$
}

${ }^{1}$ Joint Directorate of the Mordovia State Nature Reserve and National Park «Smolny», 430005, Krasnaya str., 30, Republic of Mordovia,
Russia. E-mail: ruchin.alexander@gmail.com.
${ }^{1}$ ФГБУ «Объединенная дирекция Мордовского государственного природного заповедника имени П.Г. Смидовича и национального
парка «Смольный», 430005, ул. Красная, 30, Республика Мордовия, Россия.
${ }^{2}$ Naturalis Biodiversity Center, Darwinweg 2, Leiden, Zuid-Holland, Netherlands.

KEYWORDS: new species, Mordovia State Nature Reserve, National Park «Smolny», biology.

КЛЮЧЕВЫЕ СЛОВА: новые виды, Мордовский заповедник, национальный парк «Смольный», биология.

ABSTRACT. The findings of five tachinid (Diptera) species are reported from the territory of Russia for the first time: Carcelia falenaria, Clemelis massilia, Loewia nudigena, Peribaea longirostris, Spallanzania quadrimaculata. Data on the identified specimens from Mordovia republic is provided and the habitat of the species is briefly described.

РЕЗЮМЕ. Впервые на территории России зафиксированы находки пяти видов тахинид (Diptera): Carcelia falenaria, Clemelis massilia, Loewia nudigena, Peribaea longirostris, Spallanzania quadrimaculata. Приведены данные об изученных образцах из Республики Мордовия и кратко описаны местообитания каждого вида.

Tachinidae is a diverse family and includes species that are parasitoids of Lepidoptera, Coleoptera, Hemiptera, Orthoptera and other insects [Stireman et al., 2006]. A full host catalogue for Palaearctic Tachinidae is provided by Tschorsnig [2017]. Imagos feed on flower nectar (Apiaceae, Euphorbiaceae, Asteraceae) and honeydew secreted by aphids and coccidae [Tschorsnig et al., 2003; Tooker et al., 2006; Krivosheina, Richter, 2015].

According to the latest catalogues, the world fauna includes more than 8,500 species of Tachinidae from four subfamilies. The diversity of the Tachinidae of Palaearctic fauna reaches 2108 known species [O'Hara et al., 2019; Stireman et al., 2019]. In Russia, more than 700 species are known, but there is still no complete list of representatives from this family. The genus Carcelia Robineau-Desvoidy, 1830 includes 127 species worldwide, of wich only 11 species have so far been found in Russia [O'Hara et al., 2019]. The genus Clemelis Robineau-Desvoidy, 1863 includes six species, of which only
C. pullata (Meigen, 1824) was found in Russia [O'Hara et al., 2019]. The genus Loewia Egger, 1856 includes 17 species, of which seven species are found in Russia [O'Hara et al., 2019]. The genus Peribaea RobineauDesvoidy, 1863 includes 51 species, of which three species $P$. apicalis Robineau-Desvoidy, 1863, P. setinervis (Thomson, 1869) and P. tibialis (Robineau-Desvoidy, 1851) are found in Russia [O'Hara et al., 2019]. The genus Spallanzania Robineau-Desvoidy, 1830 includes 15 species, of which only $S$. griseiventris Herting, 1967 and $S$. hebes (Fallén, 1820) are found in Russia [O'Hara et al., 2019].

The research was conducted within the territory of the Republic of Mordovia in 2017-2019 (Russia). The material was determined according to the latest identification keys relevant to the study area. The complete works by Mesnil [1944-1975] for the Palaearctic region and Zimin et al. [1969] for the European part of the Sovjet Union are useful, but slightly outdated. Important keys are provided by Tschorsnig and Herting [1994] for central Europe and Cerretti [2010] for Italy. The genera Carcelia and Clemelis have been revised by Herting [1977], Spallanzania by Herting [1967] and Peribaea by Andersen [1996].

To reliably determine some species, we studied the male genital structures in situ. The material description includes complete label data with coordinates, dates, geographical indication, and the material collector. The distribution of species was indicated mainly according to O'Hara et al. [2019] with some new entries.

$$
\text { Carcelia falenaria (Rondani, 1859) }
$$

Fig. 1.

MATERIAL. 19 - Russia, Republic of Mordovia, Ichalki district, National Park «Smolny», forestry Kemlyanskoe, quarter 87, $54.7444^{\circ} \mathrm{N}, 45.2796^{\circ} \mathrm{E}, 3 . \mathrm{VI} .2020$, leg. G.Semishin.

How to cite this article: Ruchin A.B., Zeegers T., Esin M.N. 2021. New species Tachinid flies (Diptera: Tachinidae) in the Russian fauna // Russian Entomol. J. Vol.30. No.2. P.196-199. doi: 10.15298/rusentj.30.2.15 

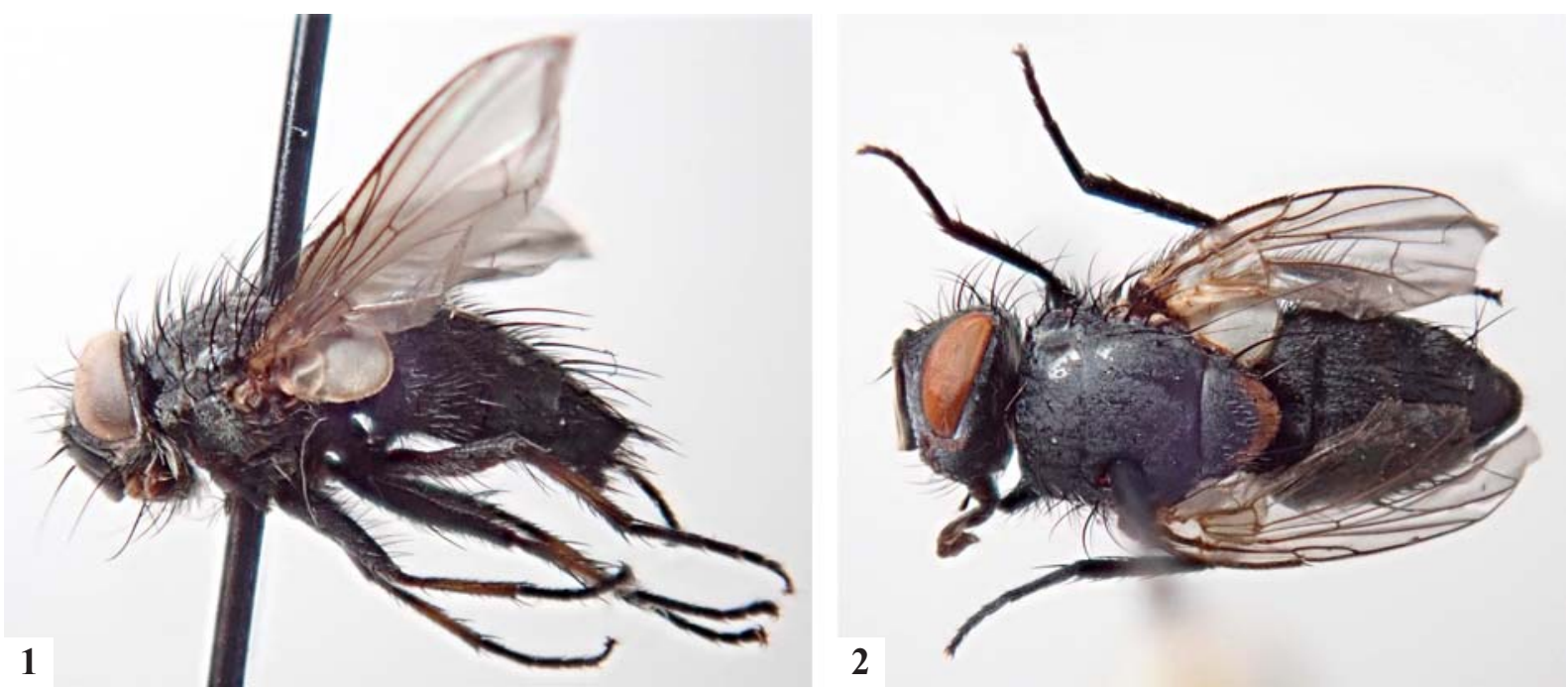

Figs 1-2. Habitus: 1 - Carcelia falenaria, female, lateral; 2 - Clemelis massilia, male, dorsal.

Рис. 1-2. Внешний вид: 1 - Carcelia falenaria, самка, сбоку; 2 - Clemelis massilia, самец, сверху.

DISTRIBUTION. Palaearctic: Europe (E. Europe (Belarus, Czech Republic, Hungary, Poland, Slovakia, Ukraine), S. Europe (Bulgaria, Croatia, Greece, Italy, Macedonia), W. Europe (Austria, Germany, Switzerland), Middle East (Israel).

BIOLOGY. Parasitoid on Lepidoptera Erebidae of the genus Amata Fabricius, 1807 [Tschorsnig, 2017; Scaramozzino et al., 2020]. In the conditions of central Russia, including the Republic of Mordovia, the probable host is the only representative of the family Erebidae close to Amata, Syntomis (=Amata) nigricornis Alphéraky, 1883. The female of $C$. falenaria was captured in a pine forest with a well-defined shrub layer. Hardwoods (Euonymus verrucosa Scop., Sorbus aucuparia L., Frangula alnus Mill.) grow from shrubs and trees of the second tier. The herb layer is poorly expressed and is represented by Convallaria majalis L., various Poaceae and Asteraceae.

Clemelis massilia (Herting, 1977)

\section{Fig. 2.}

MATERIAL. $10^{7}-$ Russia, Republic of Mordovia, Ichalki district, National Park «Smolny», forestry Kemlyanskoe, quarter 87, $54.7444^{\circ} \mathrm{N}, 45.2796^{\circ} \mathrm{E}, 12-14$. VII.2019, leg. G.Semishin.

DISTRIBUTION. Palaearctic: Europe (Italy, Spain, France), Middle East (Israel), North Africa (Canary Islands).

BIOLOGY. A host of this species has recently been recorded for the first time [Scaramozzino et al., 2020]. This is Lobesia botrana (Denis et Schiffer-Müller, 1775), Tortricidae. Clemelis massilia is thought to develop in a single host species [Tschorsnig et al., 2011]. However, this has not yet been reliably confirmed. Lobesia botrana is found in some southern regions of Russia, but it has not been reliably recorded further than the Samara region [Anikin et al., 2017]. The biotope of the Clematis massilia find is similar to the previous species.

\section{Loewia nudigena Mesnil, 1973}

\section{Fig. 3.}

MATERIAL. 1 ㅇ, $20^{7} 0^{7}-$ Russia, Republic of Mordovia, Temnikov district, Mordovia State Nature Reserve, quarter 435 , $54.7297^{\circ} \mathrm{N}, 43.1276^{\circ} \mathrm{E}, 25 . V I .2018,23 . V I I .2018$, leg. G.Semishin; $10^{7}-$ same label, Plotomoyka cordon, $54.8932^{\circ} \mathrm{N}$, $43.1611^{\circ} \mathrm{E}, 28 . \mathrm{VI} .2018$, leg. G.Semishin; $10^{7}-$ Bolshoe Ignatovo district, National Park «Smolny», forestry Aleksandrovskoe, quarter $3,54.8774^{\circ} \mathrm{N}, 45.4864^{\circ} \mathrm{E}, 2$. VII.2018, leg. G.Semishin; 1 으-Ichalki district, National Park «Smolny», forestry Lvovskoe, quarter $3,54.8735^{\circ} \mathrm{N}, 45.3060^{\circ} \mathrm{E}, 19 . \mathrm{VIII} .2018$, leg. G. Semishin; 1 ㅇ - Ichalki district, National Park «Smolny», forestry Kemlyanskoe, quarter $106,54.7264^{\circ} \mathrm{N}, 45.2624^{\circ} \mathrm{E}, 20$.VII.2018, leg. G.Semishin.

DISTRIBUTION. Palaearctic: Europe (E. Europe (Czech Republic), S. Europe (Andorra, Italy, Spain), W. Europe (Austria, France, Germany, Switzerland)).

BIOLOGY. All known hosts for the genus Loewia Egger, 1858 are centipedes (Lithobiidae) [Tschorsnig, 2017]. The species was found in five localities which are deciduous and mixed forests with a high species diversity of shrub and herb layers.

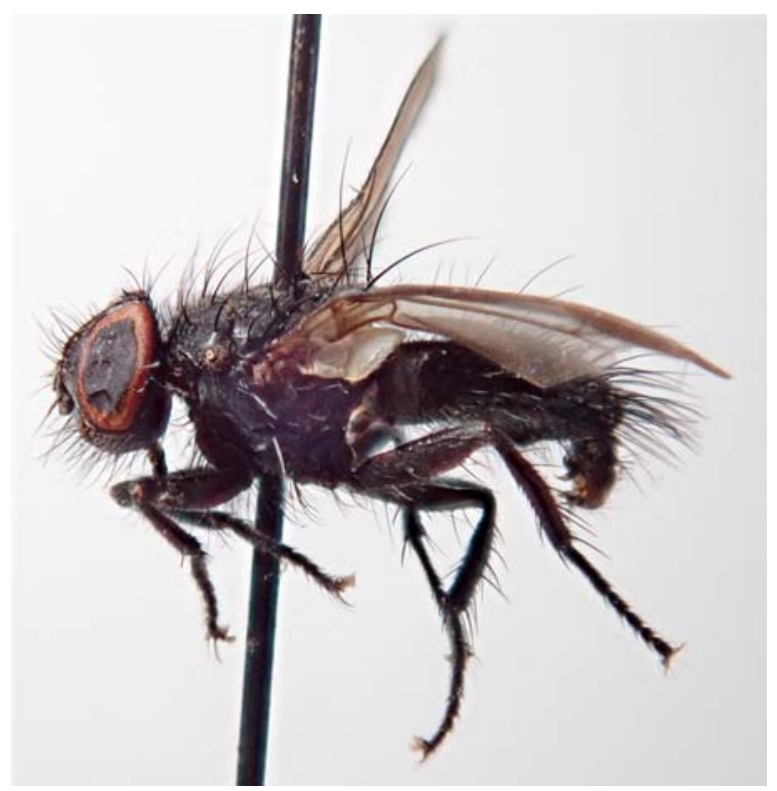

Fig. 3. Habitus of Loewia nudigena, male, lateral.

Рис. 3. Внешний вид Loewia nudigena, самец, сбоку. 

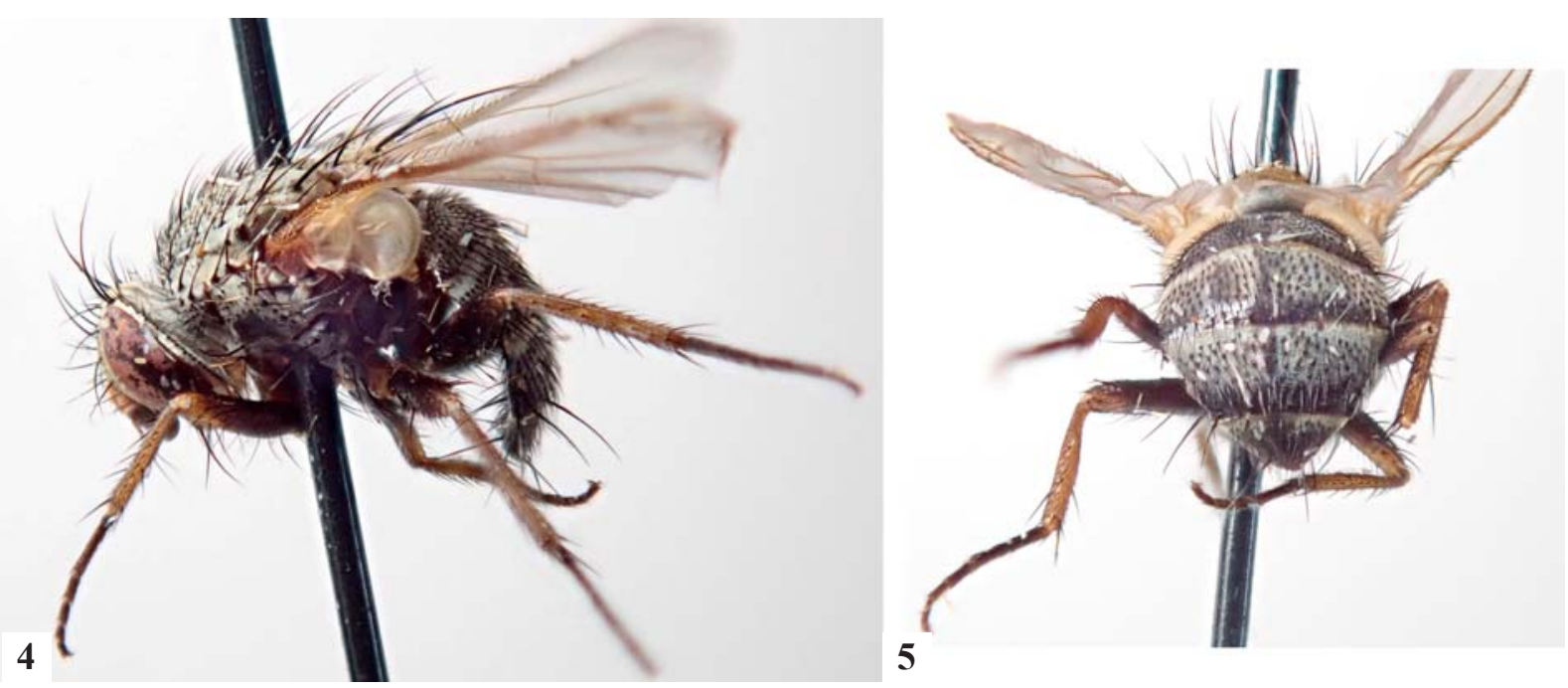

Figs 4-5. Habitus of Peribaea longirostris, female: 4 - lateral; 5 - posteriorly.

Рис. 4-5. Внешний вид Peribaea longirostris, самка: 4 - сбоку; 5 - сзади.

Peribaea longirostris Andersen, 1996 Figs 4-5.

MATERIAL. 19 - Russia, Republic of Mordovia, Temnikov district, Mordovia State Nature Reserve, Drozhdenovskiy cordon, $54.7344^{\circ} \mathrm{N}, 43.3104^{\circ} \mathrm{E}, 1 . \mathrm{VI} .2019$, leg. G.Semishin; 1 우 — Russia, Moscow, N.W., $55.78^{\circ}$ N, $37.40^{\circ}$ E, 1.VII.2010, leg. G.W.A.Pennards.

DISTRIBUTION. Palaearctic: Europe (Czech Republic, Lithuania, Italy, Germany, Netherlands, Switzerland).

BIOLOGY. This is a cryptic and likely often overlooked species. It can be separated from its closest relatives by the very narrow, yellow borders on tergites. There is little data on the biology of the species. The host is unknown. Other species of Peribaea Robineau-Desvoidy, 1863 are polyphagous on Lepidoptera [Tschorsnig, 2017]. It is quite rare in Central Europe, and prefers transparent forest edges, shrubs, and heather [Lutovanovas et al., 2015]. The surrounding biotope is a mixed forest. In the first tier, there are Pinus sylvestris L. with Betula pendula Roth and Populus tremula L. The second tier and shrubs are represented by $S$. aucuparia, Padus avium Mill., Salix sp. The forest surrounds a large clearing, where the herbaceous vegetation is very abundant in species diversity and cover density.
Spallanzania quadrimaculata Herting, 1967

Figs 6-7.

MATERIAL. $19-$ Russia, Republic of Mordovia, Ichalki district, National Park «Smolny», forestry Barakhmanovskoe, quarter $93,54.7630^{\circ} \mathrm{N}, 45.4779^{\circ} \mathrm{E}, 2$.VII.2017, leg. G.Semishin; $20^{7} \mathrm{O}^{7}$ - National Park «Smolny», forestry Kemlyanskoe, quarter 87, $54.7444^{\circ} \mathrm{N}, 45.2796^{\circ} \mathrm{E}, 12-14$. VII.2019, leg. G.Semishin; $10^{7}-$ National Park «Smolny», forestry Kemlyanskoe, quarter 93, $54.7450^{\circ} \mathrm{N}, 45.3910^{\circ} \mathrm{E}, 6$.VIII.2018, leg. G.Semishin; 1 우 — Bolshie Berezniki district, $9 \mathrm{~km} \mathrm{~S}$ of Simkino, $54.1758^{\circ} \mathrm{N}, 46.1651^{\circ} \mathrm{E}$, 12.07.2019, leg. S.Lukiyanov.

DISTRIBUTION. Palaearctic: Europe (E. Europe (Hungary), S. Europe (Greece, Italy), W. Europe (Switzerland)). Turkey [Kara et al., 2020], Kazakhstan (collection second author).

BIOLOGY. The host is still unknown, but other species of Spallanzania Robineau-Desvoidy, 1830 are predominantly found in Noctuidae associated with grasses [Tschorsnig, 2017]. It is found in four localities, which are pine forests, mixed forests and floodplain broad-leaved forests. The vegetation in all biotopes is diverse and significantly different from each other.
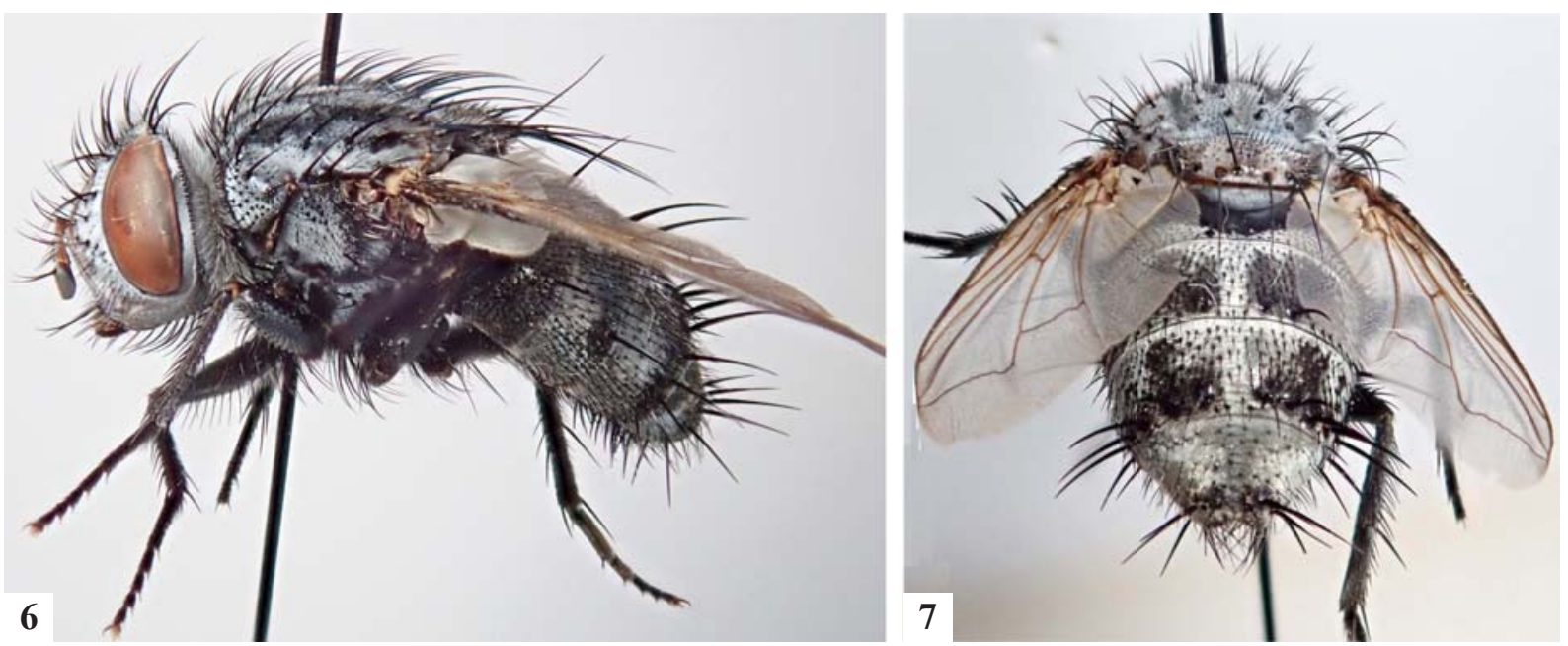

Fig. 6-7. Habitus of Spallanzania quadrimaculata, female: 6 - lateral; 7 - posteriorly.

Рис. 6-7. Внешний вид Spallanzania quadrimaculata, самка: 6 - сбоку; 7 - сзади. 
Thus, we indicate five new species of Tachinidae from five genera for the fauna of Russia. All of them are collected within the territory of the Republic of Mordovia. The main habitats of the species are woodlands of various types. All but one of the mentioned species have a predominantly southern distribution in Europe. This illustrates that the southern faunal element is relatively well developed in Mordovia republic.

Acknowledgements. The authors are grateful to G. Semishin and S. Lukiyanov (Russia) for their help in collecting the material and to L. Bolshakov (Russia) for their help in consulting on the distribution of Lepidoptera. The authors are also grateful to E. Aksenenko (Russia) for their consulting support and Gerard Pennards for sharing his material collected in the vicinity of Moscow (Russia).

Competing interests. The authors declare no competing interests.

\section{References}

Andersen S. 1996. The Siphonini (Diptera: Tachinidae) of Europe // Fauna Entomologica Scandinavica. Vol.33. P.1-148.

Anikin V.V., Sachkov S.A., Zolotuhin V.V. 2017. "Fauna lepidopterologica Volgo-Uralensis": from P. Pallas to present days // Proceedings of the Museum Witt. Bd.7. Munich-Vilnius. 696 p.

Cerretti P. 2010. I Tachinidi della fauna Italiana (Diptera, Tachinidae) con chiave interattiva dei generi ovest-paleartici. Verona. Vol.1. 573 pp.; Vol.2. 339 pp.

Herting B. 1967. Beiträge zur Kenntnis der europäischen Raupenfliegen X // Stuttgarter Beiträge zur Naturkunde. Serie A. Bd.173. S.1-11.

Herting B. 1977. Beiträge zur Kenntnis der europäischen Raupenfliegen XIV // Stuttgarter Beiträge zur Naturkunde. Serie A. VolBd.295. S.1-16.

Kara K., Tschorsnig H.-P., Atay T. 2020. Checklist of Turkish Tachinidae (Insecta, Diptera) with new records // J. Entomol. Res. Soc. Vol.22. No.2. P.163-190.

Krivosheina M.G., Richter V.A. 2015. [Tachinid flies (Diptera: Tachinidae), pollinators of aboriginal and alien species of the umbel plants (Apiaceae) in Moscow Region (Russia)] // Caucasian Entomological Bull. Vol.11. No.1. P.215-220 [in Russian]. Lutovinovas E., Barták M., Vonička P., Mückstein P. 2015. Tachinidae (Diptera) of the Jizerské hory Mts, Fr dlant region and Liberec environs (northern Bohemia, Czech Republic) // Sborník Severočeského Muzea. Přírodní Vědy. Vol.33. P.205-234.

Mesnil L.P. 1944-1975. Larvaevorinae (Tachininae) // Die Fliegen der paläarktischen Region. Teil 64g. Stuttgart. $1435 \mathrm{~S}$.

O'Hara J.E., Henderson S.J., Wood D.M. 2019. Preliminary checklist of the Tachinidae of the world. Version 1.0. PDF document, 681 p. Available at: http://www.nadsdiptera.org/Tach/WorldTachs/Checklist/Worldchecklist.html (accessed [insert date accessed]).

Scaramozzino P.L., Di Giovanni F., Loni A., Gisondi S., Lucchi A., Cerretti P. 2020. Tachinid (Diptera, Tachinidae) parasitoids of Lobesia botrana (Denis \& Schiffermüller, 1775) (Lepidoptera, Tortricidae) and other moths // ZooKeys. Vol.934. P.111-140. https://doi.org/10.3897/zookeys.934.50823.

Stireman J.O. III, Cerretti P., O’Hara J.E., Blaschke J.D., Moulton J.K. 2019. Molecular phylogeny and evolution of world Tachinidae (Diptera)// Molecular Phylogenetics and Evolution. Vol.139. 106358. https://doi.org/10.1016/j.ympev.2018.12.002.

Stireman J.O., O'Hara J.E., Wood D.M. 2006. Tachinidae: evolution, behavior, and ecology // Ann. Rev. Entomol. Vol.51. P.525-555.

Tooker J.F., Hauser M., Hanks L.M. 2006. Floral host plants of Syrphidae and Tachinidae (Diptera) of Central Illinois // Ann. Entomol. Soc. Am. Vol.99. No.1. P.96-112.

Tschorsnig H-P. 2017. Preliminary host catalogue of Palaearctic Tachinidae (Diptera). http://www.nadsdiptera.org/Tach/WorldTachs/CatPalHosts/Home.html.

Tschorsnig H.-P., Herting B. 1994. Die Raupenfliegen (Diptera: Tachinidae) Mitteleuropas: Bestimmungstabellen und Angaben zur Verbreitung und Ökologie der einzelnen Arten // Stuttgarter Beiträge zur Naturkunde. Ser.A. Bd.506. S.1-170.

Tschorsnig H-P., Seris E., Cobo A., Cobos G., Pascual S., Ros J.P., Gonzalez-Nuñez M. 2011. Tachinidae (Diptera) collected in traps used for mass-trapping of Bactrocera oleae (Rossi) (Diptera: Tephritidae) in olive groves in Central Spain // Spanish Journal of Agricultural Research. Vol.9. No.4. P.1298-1306.

Tschorsnig H.-P., Ziegler J., Herting B. 2003. Tachinid flies (Diptera: Tachinidae) from the Hautes-Alpes, France // Stuttgarter Beiträge zur Naturkunde. Ser.A (Biologie). Vol.656. P.1-62.

Zimin L.S., Zinoveva K.B., Shtakelberg A.A. 1969. [Family Tachinidae (Larvaevoridae)] // Bei-Bienko G.Ya. (ed.). Opredelitel nasekomykh Evropeyskoy Chasti SSSR. Vol.5. Pt.2. Leningrad. P.678-798 [in Russian]. 